\title{
DETERMINAN YANG BERHUBUNGAN DENGAN TINDAKAN KEBERSIHAN DIRI SANTRIWATI DI PONDOK PESANTREN X JOMBANG
}

\author{
Putaka Mastar Purnamasari dan Hario Megatsari \\ Departemen Promosi Kesehatan dan Ilmu Perilaku \\ Fakultas Kesehatan Masyarakat Universitas Airlangga \\ Email: puput.puput93@gmail.com
}

\begin{abstract}
Action of personal hygiene is one of the efforts that can be done to maintain health in Islamic boarding school environment. In the implementation there are many female students who ignore it by exchanged personal items. This research purposed to determine association knowledge and attitude as predisposing factors, towards action of personal hygiene female students which supported by infrastructure and facilities of boarding school as enabling factor, and hygiene regulation as reinforcing factor in X Jombang Islamic boarding school. This research was an analytical study with cross sectional design. The population was 90 female students then obtained 48 female students as sampling by used simple random sampling. Independent variables studied included knowledge and attitudes about personal hygiene. While the dependent variable studied the action of personal hygiene female students. Instruments used a questionnaire. Data analysis techniques performed by using the chi square test to see whether or not an association between knowledge and attitude with action of personal hygiene. Variables studied and have a relationship with action of personal hygiene female students if fulfill the requirement $p<0.05$. From the statistic test show that knowledge has any association with action of personal hygiene female students with $p=0.000(p<0.05)$ and cofficient contingensy at 0.593 . So the conclusions of this research is, there was any association between knowledge of personal hygiene with action of personal hygiene female students in X Jombang Islamic boarding school. Infrastructure and facilities was adequate and there was a regulation about hygiene in this boarding school.
\end{abstract}

Keyword: predisposing, enabling, reinforcing, action of personal hygiene

\begin{abstract}
Abstrak: Tindakan kebersihan diri merupakan salah satu upaya yang bisa dilakukan untuk menjaga kesehatan di lingkungan pondok pesantren. Saat ini masih banyak santriwati yang mengabaikannya dengan saling bertukar barang pribadi. Penelitian ini bertujuan untuk menganalisis hubungan pengetahuan dan sikap dengan tindakan kebersihan diri santriwati sebagai faktor predisposisi. Didukung dengan sarana dan prasarana pondok sebagai faktor pendorong dan peraturan kebersihan sebagai faktor penguat di Pondok Pesantren X Jombang. Penelitian ini merupakan jenis penelitian analitik dengan pengambilan data cross sectional. Populasi dalam penelitian ini adalah 90 santriwati di pondok pesantren X Jombang. Berdasarkan teknik simple random sampling didapatkan total sampel sebanyak 48 santriwati. Variabel bebas dalam penelitian ini yakni pengetahuan dan sikap santriwati mengenai tindakan kebersihan diri. Sedangkan variabel tergantung yakni tindakan kebersihan diri santriwati. Instrumen yang digunakan yakni berupa kuesioner. Teknik analisa data dilakukan dengan menggunakan uji chi square untuk melihat ada atau tidaknya hubungan. Variabel yang diteliti dan memiliki hubungan dengan tindakan kebersihan diri santriwati apabila memenuhi syarat $p<0,05$. Hasil yang diperoleh pada penelitian ini, pengetahuan memiliki hubungan dengan tindakan kebersihan diri santriwati dengan nilai $p=0,000(p<0,05)$ dengan cofficient contingency sebesar 0,593. Kesimpulan dari penelitian ini yakni adanya hubungan antara pengetahuan mengenai kebersihan diri dengan tindakan kebersihan diri santriwati, sarana dan prasarana pondok yang memadai, dan terdapat peraturan kebersihan di Pondok Pesantren X Jombang.
\end{abstract}

Kata kunci: predisposisi, pendorong, penguat, tindakan kebersihan diri, santriwati

\section{PENDAHULUAN}

Menurut UU Kesehatan Nomor 36 Tahun 2009, kesehatan adalah keadaan sehat baik secara fisik, mental, spiritual maupun sosial, yang memungkinkan setiap orang hidup produktif secara sosial dan ekonomis. Sehat merupakan hak asasi setiap manusia agar hidup menjadi lebih produktif. Kondisi badan yang sehat membuat hidup menjadi lebih sejahtera, oleh karena itu setiap orang wajib menjaga dan memelihara kesehatannya. Tidak terkecuali para santriwati yang hidup di lingkungan 
pesantren. Pesantren adalah suatu tempat yang tersedia untuk para santriwati dalam menerima berbagai pelajaran agama Islam sekaligus tempat berkumpul dan tempat tinggalnya (Qomar, 2007).

Salah satu cara menjaga agar kondisi badan tetap sehat adalah dengan menjaga dan memelihara kebersihan diri atau yang biasa dikenal dengan personal hygiene. Kebersihan perorangan atau personal hygiene adalah suatu tindakan untuk memelihara kebersihan dan kesehatan seseorang untuk kesejahteraan, baik fisik maupun psikisnya (Isro'in \& Andarmoyo, 2012). Menurut Departemen Kesehatan (2007), pada umumnya kebersihan diri santriwati kurang diperhatikan. Hal ini didukung dengan perilaku tidak sehat, seperti menggantung pakaian di kamar, tidak membolehkan pakaian santriwati putri dijemur di bawah terik matahari, dan saling bertukar pakai benda pribadi, seperti sisir dan handuk. Akibatnya apabila ada salah satu santriwati yang memiliki penyakit maka persebaran penyakit menjadi lebih mudah, utamanya penyakit menular yang bisa menular melalui kontak fisik, maupun udara.

Menurut Handri (2010), beberapa penyakit yang banyak terjadi di pondok pesantren yang penularannya mudah karena tidak sadar akan pentingnya menjaga kebersihan diri dan lingkungannya yakni scabies, diare, dan ISPA. Menurut penelitian yang dilakukan oleh Ekaningtyas (2011), disalah satu pondok pesantren yang berada di Jombang, pada umumnya perilaku santri masih mengabaikan standart kesehatan seperti kurang menjaga kebersihan diri dan sering meminjam barang milik temannya. Kondisi kesehatan yang terjadi, terutama penyakit infeksi masih tinggi. Hal ini dibuktikan dengan adanya penyakit scabies yang banyak diderita oleh santri. Scabies merupakan penyakit kulit yang disebabkan karena adanya bakteri sarcoptes scabei.

Penyakit scabies merupakan indikator bahwa perilaku kebersihan diri kurang baik. Sungkar (2000), mengatakan bahwa di pesantren yang padat penghuni dan higienenya buruk penderita scabies dapat mencapai $78,7 \%$ tetapi pada kelompok higiene baik prevalensinya hanya $3,8 \%$.
Menurut A.R Dongre (2006) Kebersihan perorangan memiliki dampak yang signifikan untuk mengurangi berbagai penyakit seperti kutu, cacing, dan kudis. Seseorang dikatakan personal hygienenya baik bila yang bersangkutan dapat menjaga kebersihan tubuhnya yang meliputi kebersihan kulit, kuku, rambut, mulut dan gigi, pakaian, mata, hidung, dan telinga serta kebersihan alat kelamin. (Badri, 2003).

Kebersihan kulit dapat dijaga dengan mandi minimal dua kali sehari, setelah mandi mengeringkan tubuhnya menggunakan handuk, dan berganti pakaian secara rutin. Kebersihan kuku dapat dijaga dengan memotong kuku secara rutin minimal setiap seminggu sekali dan mencuci tangan sesaat sebelum makan dan sesudah melakukan berbagai hal menggunakan air yang mengalir dan sabun. Kebersihan rambut dapat di jaga dengan keramas menggunakan shampo minimal satu hingga dua kali dalam seminggu. Kebersihan mulut dan gigi dapat dijaga dengan teratur menggosok gigi sesudah makan dan sebelum tidur menggunakan sikat gigi dan pasta gigi. Kebersihan mata dapat dijaga dengan membersihkannya dengan benar saat mata kotor. Kebersihan hidung dijaga dengan membersihkan hidung dengan mendenguskan hidung pelan-pelan tanpa ditutup salah satu sisinya. Kebersihan telinga dapat dijaga dengan membersihkannya minimal seminggu sekali menggunakan cotton buds. Kebersihan kaki dapat dijaga dengan mencuci kaki secara rutin dan menggeringkannya dengan handuk serta menggunakan kaos kaki dengan bahan yang sesuai (Badri, 2003). Kebersihan kelamin dapat dijaga dengan berganti celana dalam secara rutin dan pembalut pada saat menstruasi (Ariyani, 2012).

Pondok Pesantren X merupakan salah satu pondok pesantren modern yang terletak di kota Jombang. Pada tahun 2015 pondok pesantren ini memiliki sekitar 350 santri yang terdiri dari santri putra dan santri putri. Berdasarkan observasi pada studi pendahuluan yang dilakukan terhadap 15 santriwati, di Pondok Pesantren X Jombang masih terdapat santriwati yang saling bertukar barang pribadi, hal tersebut menunjukkan bahwa kebersihan diri 
santriwati kurang diperhatikan. Berdasarkan hal tersebut besar kemungkinan, pengetahuan dan sikap santriwati mengenai kebersihan diri juga masih kurang.

Tindakan kebersihan diri tidak hanya dipengaruhi oleh pengetahuan dan sikap saja. Menurut Lawrence Green perilaku dipengaruhi oleh tiga faktor yakni faktor predisposisi (predisposing factor), faktor pendorong (enabling factor), dan faktor penguat (reinforcing factor). Faktor predisposisi (predisposing factor) merupakan faktor yang mengawali terjadinya suatu perilaku seperti pengetahuan, sikap, dan keyakinan. Faktor pendorong (enabling factor) merupakan faktor yang memungkinkan terjadinya suatu perilaku seperti sarana dan prasarana fisik, serta keberadaan pelayanan kesehatan. Faktor penguat (reinforcing factor) merupakan faktor yang memperkuat terjadinya suatu perilaku seperti misalnya kelompok referensi dan tokoh masyarakat. Oleh karena itu penelitian ini dilakukan untuk mengetahui apakah terdapat hubungan antara pengetahuan dan sikap dengan tindakan kebersihan diri santriwati di Pondok Pesantren X di Jombang dengan memperhatikan faktor pendukung dan juga faktor pendorong yang ada di Pondok Pesantren X Jombang sebagai faktor yang mempengaruhi terjadinya suatu perilaku.

\section{METODE}

Penelitian ini merupakan penelitian analitik dengan menjelaskan hubungan pengetahuan dan sikap dengan tindakan kebersihan diri pada santriwati di Pondok Pesantren X di Jombang dengan memperhatikan faktor kemungkinan berupa sarana dan prasarana pondok dan faktor pendorong berupa peraturan kebersihan. Metode pengambilan data dilakukan secara cross sectional karena observasi atau pengumpulan data dilakukan secara sekaligus pada suatu waktu (point time approach). Penelitian dilakukan pada bulan Desember hingga bulan April Tahun 2015. Populasi dalam penelitian ini adalah seluruh santriwati yang berada di pondok pesantren X Jombang sejumlah 90 orang. Berdasarkan teknik simple random sampling untuk data proporsi diperoleh sample sebanyak 48 santriwati yang akan dijadikan subjek penelitian.

Variabel tergantung yakni tindakan kebersihan diri. Variabel bebas adalah pengetahuan dan sikap santriwati mengenai kebersihan diri. Tindakan kebersihan diri yang dimaksud dalam penelitian ini yakni segala tindakan yang dilakukan santriwati dalam menjaga kebersihan kulit, kuku, rambut, mulut dan gigi, pakaian, mata, hidung, dan telinga serta kebersihan alat kelamin. Sementara variabel bebas yakni pengetahuan dan sikap santriwati mengenai tindakan kebersihan diri. Pengetahuan yakni segala hal yang diketahui responden mengenai kebersihan diri dalam menjawab pertanyaan pada kuesioner yang diberikan. Sedangkan sikap yakni segala reaksi responden mengenai kebersihan diri yang dinyatakan dalam kuesioner menggunakan skala likert.

Pengumpulan data dilakukan dengan instrumen berupa kuesioner untuk mengetahui pengetahuan, sikap, serta tindakan kebersihan diri santriwati. Pengetahuan diukur menggunakan kuesioner benar atau salah yang dituangkan dalam 15 pernyataan. Pengetahuan dikatakan baik apabila skor yang diperoleh santriwati > median dan dikatakan kurang apabila skor $\leq$ median. Nilai median diperoleh dari hasil penjumlahan antara skor minimal dan skor maksimal yang kemudian dibagi dengan kategori yang diinginkan. Pengetahuan dikatakan baik apabila skor yang diperoleh santriwati dalam menjawab pertanyaan $>7,5$ dan dikatakan kurang apabila $\leq 7,5$. Sikap diukur menggunakan kuesioner dalam bentuk skala likert. Sikap dikategorikan baik apabila skor menunjukkan > nilai median dan dikategorikan ke dalam kurang apabila skor $\leq$ nilai median. Sikap dikatakan baik apabila skor yang diperoleh santriwati > 37,5 dan dikatakan kurang apabila skor $\leq 37,5$. Tindakan kebersihan diri dikatakan baik apabila skor $>210$ dan kurang apabila skor $\leq 210$.

Kemudian untuk memperdalam hasil penelitian dilakukan juga observasi mengenai keberadaan dan kondisi kebersihan sarana dan prasarana pondok sebagai faktor pendorong dan indepth interview untuk 
mengetahui keberadaan peraturan kebersihan di pondok sebagai faktor penguat. Teknik analisa data dilakukan dengan menggunakan uji chi square untuk mengetahui apakah terdapat hubungan antara pengetahuan dan sikap dengan tindakan kebersihan diri santriwati. Variabel yang diteliti dan memiliki hubungan terhadap tindakan kebersihan diri santriwati apabila memenuhi syarat $\mathrm{p}<0,05$. Kuat lemahnya hubungan dilihat dari nilai coefficient contingensy. Hubungan dikatakan kuat apabila nilai coefficient contingency semakin mendekati angka 1 .

\section{HASIL}

Berdasarkan hasil penelitian yang dilakukan diperoleh informasi sebagai berikut:

Berdasarkan tabel 1, diperoleh bahwa santriwati yang menjadi responden, berada pada rentang usia 12-18 tahun dengan tingkat pendidikan SMP/MTS dan SMA/ MA. Santriwati mayoritas sudah tinggal di pondok pesantren selama 1-4 tahun dan hampir dari separuh santriwati mengalami

Tabel 1. Karakteristik Santriwati Yang Menjadi Responden di Pondok Pesantren X Jombang pada Bulan April 2015.

\begin{tabular}{lcc}
\hline \multicolumn{1}{c}{ Karakteristik } & Jumlah & Persentase \\
\hline Kelompok umur & & \\
\hline 12-13 Tahun & 17 & $35,4 \%$ \\
14-15 Tahun & 15 & $31,3 \%$ \\
16-18 Tahun & 16 & $33,3 \%$ \\
Jumlah & $\mathbf{4 8}$ & $\mathbf{1 0 0 , 0 \%}$ \\
\hline Lama Tinggal & & \\
\hline$<$ 1 Tahun & 17 & $35,4 \%$ \\
1-4 Tahun & 26 & $54,2 \%$ \\
$>4$ Tahun & 5 & $10,4 \%$ \\
Jumlah & $\mathbf{4 8}$ & $\mathbf{1 0 0 , 0} \%$ \\
\hline Tingkat pendidikan & \multicolumn{2}{|}{} \\
\hline SMP/MTS & 27 & $56,3 \%$ \\
SMA/MA & 21 & $43,7 \%$ \\
Jumlah & $\mathbf{4 8}$ & $\mathbf{1 0 0 , 0} \%$ \\
\hline Status Kesehatan $\mathbf{3}$ bulan terakhir \\
\hline Sakit & 21 & $43,7 \%$ \\
Sehat & 27 & $56,3 \%$ \\
Jumlah & $\mathbf{4 8}$ & $\mathbf{1 0 0 , 0 \%}$ \\
\hline
\end{tabular}

Tabel 2. Distribusi Pengetahuan, Sikap, dan Tindakan Kebersihan Diri Santriwati di Pondok Pesantren X Jombang pada Bulan April 2015

\begin{tabular}{lcc}
\hline \multicolumn{1}{c}{ Variabel } & Jumlah & Persentase \\
\hline Pengetahuan & & \\
Kurang & 6 & $12,5 \%$ \\
Baik & 42 & $87,5 \%$ \\
\hline Sikap & & $12,5 \%$ \\
Kurang & 6 & $87,5 \%$ \\
Baik & 42 & \\
\hline Tindakan & & $14,6 \%$ \\
Kurang & 7 & $85,4 \%$ \\
Baik & 41 & $\mathbf{1 0 0 , 0} \%$ \\
\hline Jumlah & $\mathbf{4 8}$ & \\
\hline
\end{tabular}

sakit selama 3 bulan. Penyakit yang paling banyak di derita santri yakni maag sebanyak $10,4 \%$, demam $10,4 \%$, dan penyakit kulit sebanyak $8,3 \%$.

Berdasarkan tabel 2, diperoleh hasil penelitian bahwa sebagian besar responden memiliki pengetahuan, sikap dan juga tindakan kebersihan diri yang baik. Pengetahuan dan sikap santriwati baik karena mayoritas skor pengetahuan yang diperoleh santriwati $>7,5$ dan sikap santriwati $>37,5$. Tindakan kebersihan diri santri mayoritas berada pada rentang skor $>210$.

Tabel 3. Distribusi Tindakan Kebersihan Diri Santriwati di Pondok Pesantren X Jombang pada Bulan April 2015

\begin{tabular}{lcccc}
\hline \multicolumn{1}{c}{$\begin{array}{c}\text { Kebersihan } \\
\text { Diri }\end{array}$} & \multicolumn{2}{c}{ Kurang } & \multicolumn{2}{c}{ Baik } \\
\cline { 2 - 5 } & $\mathbf{N}$ & $\mathbf{\%}$ & $\mathbf{N}$ & $\mathbf{\%}$ \\
\hline Rambut & 2 & 4,2 & 46 & 95,8 \\
\hline $\begin{array}{l}\text { Tangan dan } \\
\text { kuku }\end{array}$ & 2 & 4,2 & 46 & 95,8 \\
\hline Tempat tidur & 24 & 50,0 & 24 & 50,0 \\
\hline Kulit & 0 & 0 & 48 & 100,0 \\
\hline Mulut dan gigi & 2 & 4,2 & 46 & 95,8 \\
\hline Mata & 8 & 16,7 & 40 & 83,3 \\
\hline $\begin{array}{l}\text { Telinga dan } \\
\text { hidung }\end{array}$ & 6 & 12,5 & 42 & 87,5 \\
\hline Kaki & 8 & 16,7 & 40 & 83,3 \\
\hline
\end{tabular}


Berdasarkan tabel 3, dapat diketahui bahwa mayoritas tindakan kebersihan diri santriwati mulai dari kebersihan rambut, tangan dan kuku, tempat tidur, kulit, mulut dan gigi, mata, telinga dan hidung, kaki, serta genetalia dikategorikan ke dalam kategori baik. Hanya pada kebersihan tempat tidur memiliki jumlah persentase yang seimbang. Tindakan kebersihan diri yang diukur menggunakan kuesioner dengan menanyakan bagaimana cara menjaga kebersihan, waktu membersihkan, dan frekuensi membersihkan diri sesuai dengan apa yang dilakukan oleh responden.

Berdasarkan tabel 4, dapat diketahui bahwa baik santriwati yang memiliki tingkat pendidikan SMP/MTS dan SMA/ MA sebagian besar memiliki pengetahuan dan sikap yang baik. Berdasarkan tabel 5, diperoleh hasil bahwa sebagian besar yang memiliki tindakan kebersihan diri yang baik memiliki pengetahuan dan sikap yang juga baik.

Berdasarkan hasil uji crosstab pada tabel 5, pengetahuan dengan tindakan kebersihan diri menunjukkan nilai signifikasi 0,000 sehingga $\mathrm{p}<0,05$. Maka dapat disimpulkan bahwa variabel pengetahuan memiliki hubungan dengan tindakan kebersihan diri santriwati dengan coeffiesient contigency sebesar 0,593 . Sedangkan pada hasil crosstab antara variabel sikap dengan kebersihan diri santriwati menunjukkan nilai signifikasi sebesar 0,273 sehingga $p>0,05$. Hal tersebut menunjukkan bahwa tidak ada
Tabel 4. Distribusi Pengetahuan dan Sikap Santriwati Mengenai Kebersihan Diri Berdasarkan Tingkat Pendidikan di Pondok Pesantren X Jombang pada Bulan April 2015

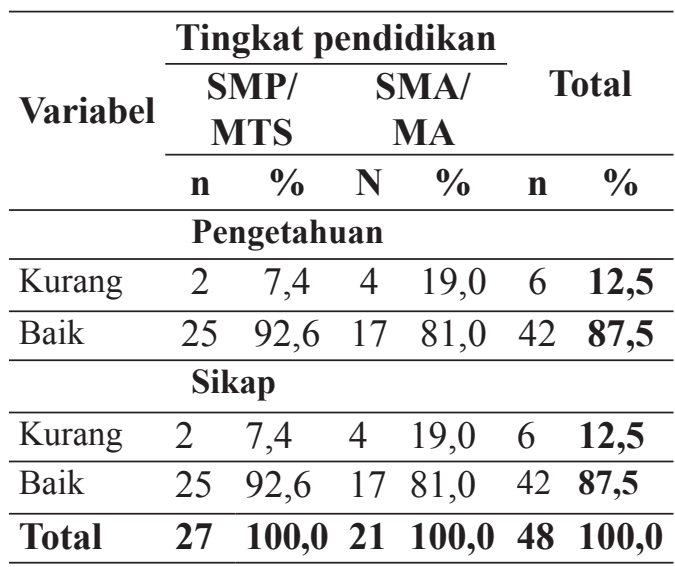

hubungan antara sikap dengan tindakan kebersihan diri santriwati.

Pada hasil observasi yang dilakukan mengenai sarana dan prasarana pondok diperoleh hasil bahwa sarana dan prasarana pondok dikategorikan ke dalam kategori baik. Sarana dan prasarana pondok yang dimaksud disini yakni keberadaan dan kondisi kebersihan kamar mandi, tempat menjemur dan mencuci baju, penyediaan air bersih, tempat pembuangan sampah, lemari pakaian, luas kamar, serta kerapian dan kebersihan kamar.

Berdasarkan hasil observasi yang dilakukan kondisi kamar mandi di Pondok Pesantren X Jombang keberadaannya

Tabel 5. Hubungan Pengetahuan dan Sikap Dengan Tindakan Kebersihan Diri Santriwati di Pondok Pesantren X Jombang pada Bulan April 2015

\begin{tabular}{|c|c|c|c|c|c|}
\hline \multirow{2}{*}{ Variabel } & \multicolumn{2}{|c|}{ Tindakan } & \multirow{2}{*}{ Total } & \multirow{2}{*}{$\mathbf{P}$} & \multirow{2}{*}{ Coefficient contingensi } \\
\hline & Kurang & Baik & & & \\
\hline \multicolumn{6}{|c|}{ Pengetahuan } \\
\hline Kurang & $\begin{array}{c}5 \\
(83,3 \%) \\
\end{array}$ & $\begin{array}{c}1 \\
(16,7 \%)\end{array}$ & $\begin{array}{c}6 \\
(100 \%)\end{array}$ & \multirow{2}{*}{0,000} & \multirow{2}{*}{0,593} \\
\hline Baik & $\begin{array}{c}2 \\
(4,8 \%)\end{array}$ & $\begin{array}{c}40 \\
(95,2 \%)\end{array}$ & $\begin{array}{c}42 \\
(100 \%)\end{array}$ & & \\
\hline \multicolumn{6}{|l|}{ Sikap } \\
\hline Kurang & $\begin{array}{c}1 \\
(50 \%)\end{array}$ & $\begin{array}{c}1 \\
(50 \%)\end{array}$ & $\begin{array}{c}2 \\
(100 \%)\end{array}$ & \multirow{2}{*}{0,273} & \multirow{2}{*}{ - } \\
\hline Baik & $\begin{array}{c}6 \\
(13 \%)\end{array}$ & $\begin{array}{c}40 \\
(87 \%)\end{array}$ & $\begin{array}{c}46 \\
(100 \%)\end{array}$ & & \\
\hline Total & $\begin{array}{c}7 \\
(14,6 \%)\end{array}$ & $\begin{array}{c}41 \\
(85,4 \%)\end{array}$ & $\begin{array}{c}48 \\
(100 \%)\end{array}$ & & \\
\hline
\end{tabular}


sudah memadai hanya saja kebersihannya kurang terjaga karena lantainya licin dan berlumut. Tempat wudhu disediakan kran air bukan lagi bak air seperti pada pondok pesantren tradisional. Keberadaan tempat menjemur dan mencuci baju juga sudah memadai dengan kondisi yang baik. Tempat menjemur baju berada langsung di bawah terik matahari. Air bersih yang di sediakan juga memenuhi syarat fisik air bersih yakni tidak keruh, tidak berbau, tidak berasa, dan tidak berwarna. Tempat pembuangan sampah juga sudah disediakan di Pondok Pesantren X Jombang, hanya saja kondisinya tidak memiliki tutup. Masih ada sampah yang hanya dibiarkan terkumpul di sudut ruangan tanpa dibuang di tempat sampah. Pada sarana berupa lemari pakaian kondisinya sudah memadai karena setiap santriwati memiliki lemari sendiri. Pada aspek luas kamar, yang idealnya $4 \mathrm{~m}^{2} /$ orang terdapat 2 dari 8 kamar yang memiliki kepadatan kurang. Kepadatan masingmasing kamar tersebut yakni sebesar 2,2 $\mathrm{m}^{2}$ /orang dan 3,5 $\mathrm{m}^{2} /$ orang. Aspek kerapian dan kebersihan kamar masih ada beberapa kamar yang tidak tertata rapi karena banyak baju bergelantungan dan banyak tidak tertata rapi. Berdasarkan hasil indepth interview untuk mengetahui peraturan kebersihan di sebagai faktor pendorong, diperoleh informasi bahwa terdapat peraturan secara tertulis mengenai kebersihan yang dibuat oleh sie divisi kebersihan di Pondok Pesantren X Jombang. Berikut penuturan nara sumber ketika ditanyakan seperti apa peraturan kebersihan yang ada di Pondok Pesantren X Jombang

"Dilarang membuang sampah sembarangan dan menaruh barang sembarangan, setiap anak wajib memiliki satu pasang sandal dan sepatu, setiap kamar wajib memiliki satu bak sampah dan sapu, santriwati wajib meletakkan sandal dan sepatu pada tempatnya serta apabila selesai melakukan amaltandif harus mengembalikan alat kebersihan dengan lengkap" (DK)

Berikut pernyataan narasumber ketika ditanyakan mengenai hukuman yang mendukung peraturan tersebut
"Beberapa bentuk hukuman yang diterapkan apabila melanggar peraturan yakni Jika ketahuan tidak mengikuti ro'an maka membersihkan kamar mandi 3 hari, jika kamar terkotor maka membersihkan aula 1 minggu, jika tidak menaruh sandal dan sepatu pada tempatnya maka harus merapikan dan membersihkan tempat sandal dan sepatu" (DK)

\section{PEMBAHASAN}

Menurut Undang-Undang Nomor 20 Tahun 2003 tentang Sistem Pendidikan Nasional, pesantren atau pondok pesantren adalah lembaga pendidikan keagamaan Islam berbasis masyarakat yang menyelenggarakan pendidikan diniyah atau secara terpadu dengan jenis pendidikan lainnya. Salah satu komponen dari pondok pesantren menurut Departemen Agama (2003) yaitu adanya santri. Santri merupakan murid yang bermukim di asrama dan belajar kepada kyai. Sehingga dalam penelitian ini responden di fokuskan kepada santri utamanya santriwati, untuk melihat faktor yang mempengaruhi kebersihan diri santri melihat masih banyaknya penyakit santriwati yang bertukar barang pribadi

Berdasarkan hasil penelitian yang dilakukan diperoleh hasil bahwa santriwati yang menjadi responden rata berada pada rentang usia 12-18 tahun, menurut Depkes (2009) rentang usia tersebut berada pada rentang usia remaja awal hingga remaja akhir. Mayoritas santriwati yang menjadi responden sudah tinggal dipesantren selama 1-4 tahun, dengan tingkat pendidikan SMP/MTS. Hal tersebut karena santriwati yang tinggal di pondok pesantren juga diwajibkan untuk menempuh pendidikan di lembaga yayasan pendidikan dan sosial milik X Jombang. Selama kurun waktu tiga bulan terakhir semenjak dilakukan penelitian, mayoritas santriwati mengatakan sehat. Demam, maag dan kulit merupakan penyakit yang banyak terjadi pada santriwati yang mengalami sakit selama kurun waktu tiga bulan. Demam merupakan gejala dari berbagai penyakit sehingga dalam hal ini demam yang dialami satriwati tidak bisa diidentifikasi mengapa bisa terjadi. Penyakit 
maag yang dialami santriwati dikarenakan beberapa santriwati tidak seberapa suka dengan makanan catering yang disediakan pondok pesantren selain itu karena padatnya aktivitas yang dilakukan sehingga santriwati terkadang lupa untuk makan. Penyakit kulit masih terjadi di Pondok Pesantren X Jombang. Menurut Depkes (2007) adanya penyakit kulit tersebut didukung oleh perilaku santri yang tidak sehat seperti, menggantung pakaian dikamar, tidak membolehkan pakaian santri dijemur di bawah terik matahari dan saling bertukar pakai benda pribadi seperti handuk dan sisir. Berdasarkan penelitian Purnamasari (2015), barang-barang yang masih banyak digunakan secara bersama yakni sisir, handuk, alat mandi, alat makan, mukena dan baju. Hanya pakaian dalam yang digunakan sendiri oleh santri. Seharusnya barang pribadi harus digunakan sendiri untuk menghindari berbagai penularan penyakit yang mudah menular. Di Pondok Pesantren $\mathrm{X}$ Jombang sendiri, masih banyak santriwati yang bertukar barang pribadi. Hal tersebut merupakan faktor yang bisa menyebabkan terjadinya penularan penyakit kulit.

Pengetahuan terjadi setelah orang melakukan penginderaan terhadap suatu objek tertentu melalui panca indera. Pengetahuan pada dasarnya terdiri dari sejumlah fakta dan teori yang memungkinkan seseorang untuk dapat memecahkan masalah yang dihadapinya. Pengetahuan tersebut diperoleh baik dari pengalaman langsung maupun melalui pengalaman orang lain (Notoatmodjo, 2014). Seseorang menjadi paham terhadap suatu hal karena adanya pengetahuan.

Berdasarkan penelitian yang dilakukan diperoleh bahwa sebagian besar pengetahuan santriwati terhadap tindakan kebersihan diri baik. Berdasarkan tingkat pendidikan mayoritas santriwati memiliki pengetahuan yang baik pada tingkat pendidikan SMP/ MTS dan SMA/MA. Pendidikan merupakan kewajiban yang harus ditempuh seseorang untuk mendapatkan pengetahuan secara formal. Menurut penelitian Utama (2006), dikatakan bahwa tingkat pendidikan formal menentukan tingkat pengetahuan seseorang. Semakin tinggi pendidikan semakin tinggi pula pemahaman seseorang tentang kesehatan dan makin besar pula perhatian terhadap kesehatan diri dan keluarganya. Tingkat pendidikan dapat mempengaruhi pola berpikir seseorang, apabila tingkat pendidikan seseorang tinggi maka cara berpikir seseorang lebih luas. Hal tersebut ditunjukkan oleh berbagai kegiatan yang dilakukannya sehari-hari (Entjang, 2000).

Pengetahuan seseorang terhadap suatu hal memiliki tingkat yang berbeda-beda, menurut Notoatmodjo (2010), tingkat pengetahuan seseorang dibedakan menjadi 6 yaitu: (1) Tahu (know), tahu hanya diartikan sebagai memanggil atau mengingat kembali sesuatu yang telah diamati sebelumnya. Pada penelitian ini santriwati tahu bahwa menjaga kebersihan diri itu penting. (2) memahami (comprehension), yang berarti bahwa seseorang tidak hanya sekedar tahu terhadap suatu objek tetapi juga dapat menginterpretasikan secara benar tentang objek tersebut. Pada penelitian ini, santriwati bukan hanya tahu tentang kebersihan diri itu penting tetapi juga dapat menjelaskan mengapa kebersihan diri itu penting. (3) Aplikasi (application), dapat diartikan bahwa apabila seseorang telah memahami suatu objek, maka seseorang dapat mengaplikasikan prinsipnya pada situasi yang lain. Pada penelitian ini santriwati sudah memahami pentingnya menjaga kebersihan diri, kemudian santriwati dapat mengaplikasikannya dengan membuat suatu yang menunjang untuk menjaga kebersihan diri, seperti dibuatlah peraturan mengenai kebersihan. (4) Analisis (analysis) merupakan indikasi bahwa pengetahuan seseorang sudah sampai pada tahap dapat membedakan, atau memisahkan dan mengelompokkan terhadap pengetahuannya akan suatu objek. Pada penelitian ini, santriwati mampu membedakan bagaimana cara- menjaga kebersihan diri yang benar dan bagaimana cara menjaga kebersihan diri yang salah. (5) Sintesis (synthesis) menunjukkan kemampuan seseorang untuk merangkum, atau meletakkan dalam suatu hubungan yang logis dari berbagai komponen pengetahuan yang dimiliki dengan pemahaman mereka sendiri. Pada penelitian ini, santriwati mampu menjelaskan kembali masingmasing cara menjaga kebersihan diri dimulai 
dari kebersihan rambut hingga kebersihan kaki termasuk didalamnya kebersihan tempat tidur dengan bahasa dan pemahaman mereka sendiri. Dan tingkatan yang terakhir yakni (6) Evaluasi (evaluation), merupakan kemampuan seseorang untuk memberikan penilaian atau justifikasi terhadap suatu objek tertentu. Pada penelitian ini, santriwati dapat menilai manfaat yang diperoleh apabila menjaga kebersihan diri dengan baik dan kerugian yang didapatkan ketika mengabaikan kebersihan diri.

Sikap merupakan kecenderungan yang berasal dari dalam diri individu untuk berkelakuan dengan pola tertentu, terhadap suatu objek akibat pendirian dan perasaan terhadap objek tersebut. Sikap tidak dapat dilihat, tetapi dapat ditafsirkan dari perilaku yang tertutup. Sikap merupakan reaksi yang bersifat emosional terhadap stimulus sosial (Maulana, 2013). Menurut Notoadmodjo (2014), sikap merupakan kesiapan atau kesediaan untuk bertindak, bukan merupakan pelaksanaan motif tertentu. Kesimpulannya sikap merupakan reaksi emosial seseorang terhadap suatu stimulus baik yang ditunjukkan dalam suatu tindakan (reaksi terbuka) maupun yang hanya berupa persepsi saja (reaksi tertutup).

Berdasarkan penelitian yang dilakukan, didapatkan bahwa sikap santriwati mengenai kebersihan diri dinyatakan baik. Berdasarkan tingkat pendidikan baik yang memiliki pendidikan SMP/MTS dan SMA/MA sebagian besar juga memiliki sikap yang baik. Hal tersebut sejalan dengan pernyataan Notoadmodjo (2007), yang menyatakan bahwa melalui pendidikan manusia akan dianggap berpengetahuan. Pengetahuan yang didukung kesadaran sikap yang positif maka akan menimbulkan perilaku yang langgeng. Apabila seseorang memiliki pengetahuan yang baik tetapi kesadaran sikapnya negatif maka tidak akan terwujud suatu perilaku yang langgeng, begitu juga sebaliknya. Perilaku yang langgeng tidak akan terbentuk apabila seseorang memiliki pengetahuan yang kurang tetapi memiliki kesadaran sikap yang positif.

Seperti halnya pengetahuan, sikap juga memiliki beberapa tingkatan berdasarkan intensitasnya. Menurut Notoatmodjo (2010), tingkatan sikap dibedakan menjadi:
(1) Menerima (receiving), yang diartikan bahwa seseorang mau menerima stimulus yang diberikan. Pada penelitian ini sikap santriwati dapat dilihat dari penerimaannya akan informasi tentang kebersihan diri (2) Menanggapi (responding), yang diartikan bahwa responden memberikan jawaban atau tanggapan terhadap pertanyaan atau objek yang dihadapi. Pada penelitian ini santriwati mau menjawab kuesioner mengenai sikap kebersihan diri yang diajukan peneliti. (3) Menghargai (valuing), yang diartikan bahwa subjek atau seseorang memberikan nilai positif terhadap suatu stimulus. Pada penelitian ini santriwati mendiskusikan kebersihan diri dengan temannya atau mengajak teman untuk menjaga kebersihan diri. (4) Bertanggung jawab (responsible) merupakan sikap yang paling tinggi tingkatannya. Pada tahap ini seseorang harus mampu mempertanggung jawabkan sikap yang diambilnya berdasarkan keyakinannya meskipun dicemooh orang lain. Pada penelitian ini santriwati yang benar-benar menjaga kebersihan dirinya harus rela mengeluarkan uang lebih untuk membeli sabun, sikat gigi, pasta gigi, shampo dan berbagai peralatan lain yang dibutuhkan untuk menunjang kebersihan dirinya

Tindakan kebersihan diri santriwati diteliti untuk melihat sebaran bagaimana tindakan kebersihan diri santriwati di Pondok Pesantren X Jombang. Kebersihan diri merupakan salah satu upaya yang bisa dilakukan untuk mengurangi terjadinya penyakit menular yang terjadi di pondok pesantren. Karena menurut Notoadmodjo (2014), suatu sikap belum otomatis terwujud dalam suatu tindakan. Agar terwujud sikap menjadi suatu perbuatan nyata diperlukan faktor pendukung berupa fasilitas dan dukungan dari pihak lain.

Berdasarkan penelitian yang dilakukan di Pondok Pesantren X Jombang, diperoleh tindakan kebersihan rambut santriwati sebagian besar baik. Kebersihan rambut dikatakan baik karena apa yang dilakukan santriwati dalam menjaga kebersihan rambut sudah sesuai dengan apa yang diungkapkan Rahardian (2008), yang menyatakan bahwa rambut harus dicuci sesering mungkin dengan shampo 1-2 kali seminggu atau sesuai kebutuhan supaya tetap bersih. 
Mengingat santriwati selalu beraktivitas menggunakan kerudung sehingga kebersihan rambut harus selalu dijaga dengan baik agar tidak terjadi masalah kebersihan rambut seperti ketombe dan kutu rambut. Menurut Ansyah (2013), penyakit kutu berhubungan dengan tindakan personal hygiene di pondok pesantren modern.

Kebersihan tangan dan kuku santriwati di Pondok Pesantren X Jombang sebagian besar tergolong baik. Dikatakan baik karena mayoritas santriwati mengatakan bahwa membersihkan kuku seminggu sekali dan mencuci tangan menggunakan sabun saat sebelum dan sesudah makan serta setelah buang air besar. Hal tersebut sejalan dengan yang diungkapkan Rahardian (2008), bahwa kebersihan tangan dapat dijaga dengan mencuci tangan. Mencuci tangan yang benar adalah saat sebelum dan sesudah makan serta setelah buang air besar. Mencuci tangan dengan air bersih dan sabun dapat mematikan semua kuman yang melekat ditangan. Selain itu untuk mencegah masuknya kuman ke dalam mulut, kuku harus dipotong secara rutin minimal setiap seminggu sekali. Tangan merupakan anggota bagian tubuh yang paling sering digunakan untuk memegang suatu benda, seringkali seseorang lupa untuk mencuci tangan setelah melakukan aktivitas kemudian makan dengan menggunakan tangan. Hal tersebut dapat menyebabkan masuknya bakteri ke dalam tubuh, sehingga kebersihan tangan harus benar-benar diperhatikan agar kondisi badan tetap sehat.

Kebersihan tempat tidur dapat dijaga dengan mencuci seprei, sarung bantal, bantal dan selimut minimal satu kali dalam seminggu. Berdasarkan hasil penelitian yang dilakukan tindakan santriwati di Pondok Pesantren X Jombang dalam menjaga kebersihan tempat tidur 50\% baik dan 50\% kurang. Hal tersebut menunjukkan bahwa $50 \%$ santriwati yang menjaga kebersihan tempat tidurnya dengan baik. Santriwati yang menjaga kebersihan tempat tidurnya kurang bisa dikatakan tidak mencuci alat-alat tidurnya setiap seminggu sekali. Selain itu berdasarkan pengamatan singkat di Pondok Pesantren X Jombang, masih banyak baju-baju bergelantungan dikamar dan buku-buku tidak tertata rapi.
Berdasarkan teori segitiga epidemiologi penyakit terjadi karena ketidakseimbangan antara host, agent, dan environment. Dalam hal ini kebersihan tempat tidur merupakan lingkungan yang digunakan secara bersama oleh santriwati sehingga harus dijaga kebersihannya. Penyakit bisa terjadi ketika perilaku santriwati dalam menjaga kebersihan diri baik tetapi tidak didukung dengan adanya kebersihan lingkungan yang juga baik. Apalagi di lingkungan pondok pesantren merupakan lingkungan yang padat penghuni. Di Pondok Pesantren X sendiri ada 2 kamar yang memiliki kepadatan hunian yang kurang dari standar oleh karena itu kebersihan kamar harus dijaga dengan baik. Diharapkan dengan mendapatkan hukuman untuk membersihkan aula selama seminggu apabila kamar merupakan kamar terkotor mampu dijadikan acuan agar santriwati mau menjaga kebersihan dan kerapian kamar.

Kebersihan kulit dapat dijaga dengan mandi secara teratur dan mandi hendaknya dilakukan dengan menggunakan sabun dan air bersih. kemudian setelah mandi dikeringkan menggunakan handuk (Rahardian, 2008). Pada kebersihan kulit, berdasarkan hasil penelitian yang dilakukan keseluruhan santriwati memiliki tindakan kebersihan kulit yang baik. Hanya saja hal tersebut tidak sesuai dengan hasil penelitian yang diperoleh bahwa salah satu penyakit yang banyak diderita santri dalam kurun waktu 3 bulan terakhir adalah penyakit kulit sebanyak $8,3 \%$. Sehingga dapat disimpulkan bahwa kejadian penyakit kulit tidak bisa dikaitkan dengan adanya kebersihan kulit dalam kasus ini. Penyakit kulit di Pondok Pesantren X Jombang, bisa terjadi karena hal lain. Berdasarkan teori segitiga epidemiologi yang dikemukakan oleh Gordon dan La Richt (1950) bahwa timbulnya suatu penyakit dipengaruhi oleh tiga faktor utama yakni host, yang merupakan tuan rumah/penjamu, agent (penyebab), dan environment. Host merupakan santriwati, penyakit kulit bisa terjadi karena kondisi santriwati yang memang rentan atau karena perilaku santriwati yang tidak sehat, agent dalam hal ini adalah bakteri yang menyebabkan penyakit kulit, dan environment merupakan lingkungan fisik 
maupun sosial yang mempengaruhi kondisi host. Di pondok pesantren X Jombang kamar mandi yang disediakan sudah memadai, sehingga santriwati dapat menjaga kebersihan kulit melalui mandi secara teratur. Tempat mencuci dan menjemur baju juga disediakan secara memadai sehingga kebersihan baju dapat dijaga dengan baik pula. Lemari pakaian sudah disediakan untuk masing-masing santriwati sehingga menghindari bercampurnya barang pribadi milik santriwati. Hanya saja masih banyak santriwati yang saling bertukar barang pribadi. Kebersihan kamar yang kurang serta kepadatan kamar yang terlalu padat dapat menyebabkan penularan penyakit kulit menjadi lebih mudah.

Berdasarkan hasil penelitian yang diperoleh, didapatkan bahwa kebersihan mulut dan gigi santri di Pondok Pesantren $\mathrm{X}$ Jombang mayoritas baik. Dikatakan baik karena santriwati menjaga kebersihan mulut dan gigi dengan menyikat gigi setiap sebelum tidur atau sesudah makan serta bangun tidur dengan menggunakan sikat gigi dan pasta gigi. Kebersihan mulut harus dijaga agar terhindar dari penyakit seperti bau mulut, sariawan, karies, gingivitis, serta penyakit periodontal. Karies merupakan kerusakan jaringan keras gigi, gingivitis merupakan peradangan pada gingiva (gusi), sedangkan periodontal adalah penyakit yang terjadi pada jaringan penyangga gigi (Isro'in \& Andarmoyo, 2012)

Kebersihan mata harus selalu dijaga untuk menghindari berbagai penyakit infeksi pada mata. Berdasarkan hasil penelitian yang dilakukan sebagian besar kebersihan mata santriwati di Pondok Pesantren $\mathrm{X}$ Jombang baik. Dikatakan baik karena apa yang dilakukan santri dalam menjaga kebersihan mata sesuai dengan apa yang diungkapkan oleh Depkes (1989), bahwa cara membersihkan mata yang kotor adalah dengan mengusap kotoran mata dari sudut mata bagian dalam kesudut mata bagian luar dengan menggunakan sapu tangan.

Kebersihan telinga dapat dijaga dengan membersihkannya menggunakan cotton buds karena membersihkan dengan peniti bisa mengakibatkan kerusakan gendang telinga (Depkes, 1989). Telinga merupakan indera pendengaran yang juga berfungsi sebagai pusat keseimbangan, sehingga apabila terjadi gangguan pada telinga bisa menyebabkan gangguan pendengaran juga keseimbangan. Oleh karena itu, menjaga kebersihan telinga sangat penting. (Isro'in \& Andarmoyo, 2012) Sedangkan menjaga kebersihan hidung dapat dilakukan dengan mendenguskannya secara perlahan. Berdasarkan hasil penelitian yang dilakukan sebagian tindakan kebersihan telinga dan hidung santri di Pondok Pesantren X Jombang baik. Karena mereka mayoritas membersihkan telinga menggunakan cotton buds.

Berdasarkan hasil penelitian yang dilakukan di Pondok Pesantren X Jombang, kebersihan kaki santriwati mayoritas baik. Dikatakan baik karena santriwati menjaga kebersihan kaki dengan mencuci kaki menggunakan sabun dan mengeringkannya menggunakan handuk sesuai dengan apa yang diungkapkan Isro'in dan Andarmoyo (2012).

Berdasarkan hasil penelitian yang dilakukan di Pondok Pesantren X Jombang, kebersihan genetalia santri sebagian besar baik. Dikatakan baik karena apa yang dilakukan santri dalam menjaga kebersihannya sesuai dengan apa yang diungkapkan oleh Ariyani (2012), bahwa membersihkan alat kelamin dilakukan dengan membersihkannya dari bagian depan kebelakang. Kemudian frekuensi berganti celana dalam yang baik adalah sebanyak dua kali sehari dan berganti pembalut saat haid yang baik adalah 4-5 kali dalam sehari untuk menghindari pertumbuhan bakteri yang dapat masuk ke dalam vagina.

Berdasarkan hasil penelitian diatas dapat disimpulkan bahwa keseluruhan tindakan kebersihan diri santri yang meliputi kebersihan rambut, kebersihan tangan dan kuku, kebersihan tempat tidur, kebersihan kulit, kebersihan mulut, kebersihan mata, kebersihan telinga dan hidung, kebersihan kaki serta kebersihan alat kelamin mayoritas baik. Sehingga pada saat dikelompokkan keseluruhannya diperoleh hasil bahwa tindakan kebersihan diri santriwati di pondok pesantren $\mathrm{X}$ Jombang sebesar sebagian besar baik.

Berdasarkan hasil penelitian yang dilakukan diperoleh informasi bahwa 
pengetahuan memiliki hubungan dengan tindakan kebersihan diri santriwati. Pengetahuan memiliki hubungan dengan tindakan kebersihan diri santriwati sebesar 0,593 . Karena berada pada rentang nol dan satu, dapat dikatakan bahwa pengetahuan memiliki hubungan yang tidak seberapa kuat dengan tindakan kebersihan diri santriwati. Dalam hal ini memang mayoritas santriwati yang memiliki pengetahuan yang baik juga memiliki tindakan kebersihan diri yang baik. Hal tersebut sesuai dengan apa yang diungkapkan Notoadmodjo (2007), yang menyatakan bahwa pengetahuan merupakan domain yang penting untuk pembentukan perilaku seseorang (overt behavior), karena perilaku yang didasari oleh adanya pengetahuan lebih bersifat langgeng daripada perilaku yang tidak didukung dengan adanya pengetahuan.

Pengetahuan diperoleh baik dari pendidikan formal maupun nonformal. Pengetahuan diperoleh seseorang berdasarkan proses belajar dari sebuah pengamatan atau penginderaan terhadap suatu objek tertentu. Salah satu faktor yang mempengaruhi pengetahuan adalah pendidikan. Pendidikan merupakan bimbingan yang diberikan oleh seseorang kepada orang lain, agar seseorang dapat memahami sesuatu. Tidak dapat dipungkiri bahwa semakin tinggi pendidikan seseorang semakin mudah pula penerimaannya terhadap suatu informasi, sehingga semakin bertambah pengetahuannya. Sebaliknya jika tingkat pendidikan seseorang rendah, akan menghambat perkembangan perilaku seseorang terhadap penerimaan terhadap suatu informasi dan nilai-nilai yang baru diperkenalkan. Pendidikan lebih menekankan pada pembentukan manusianya (penanaman sikap dan nilai-nilai) (Mubarak $\mathrm{dkk}, 2007)$. Pengetahuan yang dimiliki oleh seorang yang berpendidikan mempengaruhi keputusan seseorang untuk berperilaku sehat.

Pada variabel sikap didapatkan suatu kesimpulan bahwa sikap santriwati tidak memiliki hubungan dengan tindakan kebersihan diri. Sarwono (2000), sikap tidak sama dengan perilaku dan perilaku tidak selalu mencerminkan sikap seseorang. Individu seringkali memperlihatkan perilaku yang bertentangan dengan sikapnya, karena sikap merupakan reaksi emosional seseorang terhadap sesuatu. Melalui sikap secara minimal masyarakat memiliki pola berpikir tertentu dan pola pikir diharapkan dapat berubah dengan diperolehnya pengalaman, pendidikan, dan pengetahuan melalui interaksi dengan lingkungannya.

Apabila dikaitkan dengan teori konsistensi sikap dan perilaku menurut Azwar (2013), sikap santriwati mengenai tindakan kebersihan diri memenuhi postulat variasi independen dan postulat kontingensi tergantung. Variasi independen menyatakan bahwa sikap dan perilaku tidak memiliki hubungan yang konsisten, artinya sikap dan perilaku bukan merupakan satu kesatuan. Sikap dan perilaku merupakan dua dimensi dalam diri individu yang berdiri sendiri, terpisah, dan berbeda. Mengetahui sikap tidak berarti dapat memprediksi perilaku. Sehingga bisa dikatakan bahwa sikap tidak langsung terwujud dalam suatu perilaku atau dengan kata lainnya disebut sebagai perilaku tertutup (covert behaviour) yang merupakan respons seseorang terhadap suatu stimulus belum dapat diamati oleh orang lain secara jelas. Hal tersebut ditunjukkan dengan adanya hasil penelitian yang menunjukkan bahwa meskipun sikap santriwati mengenai kebersihan diri baik dan juga tindakan kebersihan dirinya baik keduanya tidak memiliki hubungan yang berarti. Berdasarkan postulat kontingensi tergantung, dalam hubungan sikap dan perilaku sangat ditentukan oleh berbagai faktor situasional tertentu seperti norma, peranan, keanggotaan kelompok, kebudayaan dan lain sebagainya. Oleh karena itu, sejauh mana prediksi perilaku dapat disandarkan pada sikap akan berbeda dari waktu ke waktu dan dari situasi ke situasi lainnya. Selain itu masih ada faktor lain yang mendasari adanya suatu perilaku seperti faktor pendukung dan faktor pendorong. Menurut Notoadmodjo (2003), sikap positif terhadap nilai-nilai kesehatan tidak selalu terwujud dalam suatu tindakan nyata. Hal tersebut disebabkan oleh beberapa hal, antara lain sikap akan terwujud dalam suatu tindakan tergantung pada situasi saat itu. Serta sikap akan diikuti atau tidak diikuti oleh tindakan mengacu 
kepada pengalaman pribadi dan pengalaman orang lain.

Menurut Notoatmodjo (2007), tidak semua pengetahuan dan sikap akan di wujudkan menjadi suatu tindakan atau bisa juga disebut sebagai perilaku tertutup. Respons atau reaksi terhadap stimulus pada perilaku tertutup masih terbatas pada perhatian, persepsi, pengetahuan atau kesadaran, dan sikap yang terjadi pada orang yang menerima stimulus tersebut, dan belum dapat diamati secara jelas oleh orang lain. Sehingga apabila santriwati memiliki pengetahuan dan sikap yang baik mengenai kebersihan diri, santriwati belum tentu menerapkannya dalam suatu tindakan. Hal tersebut bisa dipengaruhi oleh banyak faktor. Menurut Lawrence Green (1999), perilaku dipengaruhi oleh tiga faktor yakni faktor predisposisi yang merupakan faktor yang mengawali terjadinya suatu perilaku dalam hal ini pengetahuan dan sikap. Kemudian faktor pemungkin seperti sarana dan prasarana fisik serta faktor penguat seperti kelompok referensi dan tokoh masyarakat yang dianggap penting. Perilaku memang dipengaruhi oleh tiga faktor tersebut tetapi faktor predisposisi merupakan faktor yang mengawali terjadinya suatu perilaku sehingga diharapkan apabila faktor predisposisi sudah baik, maka faktor lainnya harus mendukung untuk terciptanya suatu perilaku yang baik. Di Pondok Pesantren $\mathrm{X}$ Jombang, pengetahuan dan sikap santriwati mengenai kebersihan sebagai faktor predisposisi sudah baik. Sarana dan prasarana yang disediakan pondok juga sudah cukup memadai. Peraturan kebersihan sebagai faktor pendorong juga sudah jelas peraturannya dan bagaimana hukuman yang diberlakukan apabila peraturan tersebut tidak dipatuhi.

\section{KESIMPULAN}

Kesimpulan dari penelitian ini yaitu santriwati yang menjadi responden mayoritas berada pada rentang usia 12-18 tahun dan sudah tinggal di pondok pesantren Al-Aqobah Jombang selama 1-4 tahun dengan tingkat pendidikan SMP/MTS dan SMA/MA. Selama kurun waktu tiga bulan terakhir mayoritas santri tidak mengalami sakit. Tetapi mereka yang sakit pada tiga bulan terakhir saat dimulai penelitian, penyakit yang paling banyak diderita yakni demam, maag, dan kulit.

Pengetahuan dan sikap santriwati mengenai tindakan kebersihan diri mayoritas baik. Hal tersebut didukung dengan adanya tindakan kebersihan diri santriwati yang juga baik. Faktor determinan yang berhubungan dengan tindakan kebersihan diri santriwati di Pondok Pesantren X Jombang yakni faktor predisposisi berupa pengetahuan. Pengetahuan tersebut didukung dengan adanya sarana dan prasarana pondok yang memadai sebagai faktor pendorong dan peraturan kebersihan yang juga memadai sebagai faktor penguat tindakan kebersihan diri santriwati, sehingga menghasilkan tindakan kebersihan diri yang juga baik.

\section{DAFTAR PUSTAKA}

Ansyah, Achmad Nur. 2013. Hubungan Personal Hygiene dengan Angka Kejadian Pediculus Capitis Pada Santri Putri Pondok Pesantren Modern Islam Assalam Surakarta 2013. Jurnal. Surakarta: Universitas Muhammadiyah Surakarta.

Ariyani. 2012. Penelitian Parasit dan Bakteri pada Akseptor KB dan Ibu Hamil yang Menderita Flour Albus.

Azwar, S. 2013. Sikap Manusia dam Pengukurannya. Yogyakarta: Pustaka Belajar Offset

Badri, Mohamad. 2003. Perubahan Pemeliharaan Kebersihan Diri Santri Melalui Pemberdayaan Ustadz di Pondok Pesantren Wali Songo Ngabar Ponorogo Tahun 2003. Tesis. Surabaya: Universitas Airlangga

Depag RI. 2003. Pola Pembelajaran di Pesantren. Jakarta: Departemen Agama RI.

Depkes RI. 1989. Perawatan I (Dasar-Dasar Perawatan) Pandangan Kini di Bidang Pendidikan Perawatan Perubahan Masalah Edisi Pertama. Jakarta: Pusdiknakes Depkes RI.

Depkes RI. 2007. Cegah dan Hilangkan Penyakit 'Khas' Pesantren. 
Dibuka pada website http://suhelmi. wordpress.com/2007/10/23/cegahdanhilangkan-penyakit-khas-pesantren/. Diakses 03 Maret 2015

Depkes RI. 2009. Profil Kesehatan Indonesia. Jakarta: Departemen Kesehatan RI

Dongre, A.R, P.R Deshmukh, B.S Garg. 2006. The Impact of School Health Education Programme on Personal Hygiene Related Morbidities in Tribal School Children of Wardha District. Indian Journal of Community Medicine Vol. 31, No.2.

Ekaningtyas, Novie Putri. 2011. Hubungan Sanitasi dan Higiene Perorangan dengan Kejadian Skabies Pada Santri Pondok Pesantren Madrasatul Qur'an Tebuireng Jombang. Skripsi. Surabaya: Universitas Airlangga.

Entjang, I. 2000. Ilmu Kesehatan Masyarakat. Bandung: Citra Aditya Bakti.

Green, Lawrence., Kreuter, Marshall W. 1999. Health Promotion Planning: An Educational and Ecological Approach. Universitas Michigan: Mayfield Publishing Company

Handri. 2010. Info kesehatan Penyakit Kulit. Jakarta.

Isro'in, Laily dan Sulistyo Andarmoyo. 2012. Personal Hygiene Konsep, Proses, dan Aplikasi dalam Praktik Keperawatan. Yogyakarta: Graha Ilmu.

Maulana, Heri D.J. 2013. Promosi Kesehatan. Jakarta: ECG.

Notoadmodjo, Soekidjo. 2003. Ilmu Kesehatan Masyarakat. Jakarta: Rineka Cipta

Notoatmodjo, Soekidjo. 2007. Promosi Kesehatan Teori dan Aplikasinya. Jakarta: Rineka Cipta
Notoatmodjo, Soekidjo. 2010. Promosi Kesehatan Teori dan Aplikasinya Edisi Revisi. Jakarta: Rineka Cipta.

Notoatmodjo, Soekidjo. 2014. Ilmu Perilaku Kesehatan. Jakarta: Rineka Cipta.

Purnamasari, Putaka Mastar. 2015. Faktor Yang Mempengaruhi Perilaku Santriwati Mengenai Tindakan Kebersihan Diri (Studi di Pondok Pesantren Al-Aqobah Jombang). Skripsi. Surabaya: Universitas Airlangga

Qomar, M. 2007. Pesantren. Yogyakarta: Erlangga.

Rahardian, Dhini Marga. 2008. Sanitasi Pondok dan Higiene Perorangan Santri di Pesantren Putri KHA. Wahid Hasyim Kecamatan Bangil Pasuruan. Skripsi. Surabaya: Universitas Airlangga.

Republik Indonesia. 2003. Undang-undang No. 20 Tahun 2003 Sistem Pendidikan Nasional. Lembaran Negara Republik Indonesia No.4301 Pendidikan. Sekretariat Negara. Jakarta.

Republik Indonesia. 2009. Undang-undang No. 36 Tahun 2009 Tentang Kesehatan. Lembaran Negara Republik Indonesia Tahun 2009 No.144. Sekretariat Negara. Jakarta.

Sarwono, Wirawan, S., 2000. Pengantar Umum Psikologi. Jakarta: PT. Bulan Biintang.

Sungkar, S. 2000. Skabies. Jakarta: Yayasan Penerbit Ikatan Dokter Indonesia.

Utama, I Dewa. 2006. Hubungan Pengetahuan dan Sikap Remaja Putra Jalanan Dengan Seks Bebas Terhhadap Tindakan Berisiko Tertular Penyakit Menular Seksual (PMS) (Studi Kasus di Kota Denpasar Provinsi Bali) Skripsi. Surabaya: Universitas Airlangga. 